\title{
MODERATISME SYAH WALIYULLAH AD-DIHLAWI (Analisis Pemikirannya dalam Kitab Al-Inshaf fi Bayani Asbab al-Ikhtilaf)
}

\author{
Achmad Subkhan \\ Balai Diklat Keagamaan Semarang \\ Subkhan1980@gmail.com
}

\begin{abstract}
Abstrak
Perbedaan pendapat dalam masalah fikih ini sudah terjadi sejak generasi sahabat, tabi'in dan imam Madzhab. Perbedaan yang terjadi pada masing-masing generasi memiliki sebab yang berbeda-beda. Konflik yang terjadi antar umat Islam salah satunya dipicu oleh perbedaan pendapat dalam masalah hukum Islam. Konflik ini menguat setelah abad ke empat Hijriyah. Agar konflik dapat diminimalisasi, dibutuhkan sikap moderat umat Islam dengan cara mengetahui penyebab terjadinya perbedaan tersebut dan sikap ulama terdahulu dalam menghadapinya. Jenis penilitian ini merupakan penelitian kepustakaan, dengan menggunakan metode deskriptif dan pendekatan kualitatif. Adapun untuk informasi digunakan teknik content analysis (analisis isi). Penelitian ini mengungkap moderatisme Syah Waliyullah ad-Dihlawi yang ditunjukan melalui karyanya yang berjudul al-Inshaf fi Bayan Asbab al-Iktilaf. AdDihlawi memetakan sebab-sebab terjadinya perbedaan pendapat dan menyajikannya secara obyektif. Ad-Dihlawi juga mengungkapkan riwayat sikap sahabat, tabi' in dan Imam Madzhab dalam menghadapi perbedaan pendapat. Menurutnya, dalam menghadapi perbedaan, perlu meneladani sikap yang dicontohkan oleh sabahat, tabi'in dan para imam Madzhab.
\end{abstract}

Kata Kunci: Moderatisme, Syah Waliyullah ad-Dihlawi, Perbedaan Pendapat

\begin{abstract}
The difference of opinion on the issue of fiqh has occurred since generations of companions, tabi'in and priests of madhhab. The differences that occur in each generation have different causes. One of the conflicts that occurred between Muslims was triggered by differences of opinion on issues of Islamic law. This conflict intensified after the fourth century Hijriyah. In order for conflicts to be minimized, a moderate attitude of Muslims is needed by knowing the causes of these differences and the attitudes of previous scholars in dealing with them. The type of this research is library research, using descriptive methods and qualitative approaches. As for revealing information used content analysis techniques (content analysis). This study reveals the moderateism of Syah Waliyullah ad-Dihlawi which is shown through his work entitled al-Inshaffi Bayan Asbab al-Iktilaf. Ad-Dihlawi mapped the causes of differences of opinion and presented them objectively. Ad-Dihlawi also revealed a history of the attitude of friends, tabi'in and priests of madhhab in dealing with differences of opinion. According to him, in dealing with differences, it is necessary to imitate the attitude exemplified by companions, tabi'in and priests of madhhab.
\end{abstract}

Keywords: moderatisme, Syah Waliyullah ad-Dihlawi, the difference of opinion 


\section{A. PENDAHULUAN}

Seruan gagasan moderasi beragama di Indonesia dimulasi sejak tahun 2016 oleh Menteri Agama Lukman Hakim Saifudin, waktu itu. Seruan ini mendahului Tahun Moderasi yang dicanangkan oleh Persatuan Bangsa-Bangsa (PBB), pada tahun 2019. Seruan moderasi beragama ini bukannya tanpa dasar, melainkan merupakan seruan yang sejalan dengan ajaran agama.

Melihat fenomena radikalisme agama yang semakin mengkhawatirkan, kiranya seruan moderasi beragama memang harus senantiasa bergema setiap saat. Hal ini merupakan upaya untuk membendung arus paham radikalisme yang semakin memprihatinkan. Meskipun ketika berbicara tentang radikalisme kita tidak bisa berlepas dari dimensi yang luas, namun suara yang terdengar, radikalisme sering dihubungkan dengan ajaran agama.

Beberapa peristiwa radikalisme, sering dikaitkan dengan agama Islam. Hal ini memang tidak bisa dipungkiri, bahwa pelaku radikalisme yang terekpos oleh media lebih banyak dilakukan oleh orang Islam. Sejalan dengan hal ini, muncul gerakan yang menarasikan kontra radikalisme, di antaranya; radikalisme bukanlah ajaran agama Islam, pelaku radikalisme bukan manifestasi ajaran agama Islam, dan terakhir adalah Islam agama pembawa rahmat.

Narasi-narasi tersebut di atas digaungkan untuk menunjukan kepada dunia bahwa sesungguhnya ajaran agama Islam menyeru kepada perdamaian, penuh kasih saying, anti kekerasan dan moderat. Narasi tersebut tidak hanya digaungkan oleh aktivis Islam, bahkan oleh para ulama kontemporer yang kualifikasinya diakui dunia antara lain Quraish Syihab, Nasaruddin Umar, Said Aqil Siraj, Haedar Nasir, Habib Luthfi, Habib Umar Bin Hafidz, Habib Ali Jufri dan masih banyak lagi. Mereka menarasikan Islam Agama Moderat tidak hanya melalui ceramah, namun juga melalui karya tulis.

Jauh sebelum ulama kontemporer menyuarakan tentang moderatisme, ulama-ulama abad ke 17 Masehi menyinggung tentang sikap moderat yang dinarasikan dalam bentuk menghormati perbedaan madzhab dalam ajaran agama Islam, ataupun diimlementasikan dalam bentuk tarekat. Misalnya Muhammad Hayyat al-Sindi, ia merupakan salah seorang ulama yang sezaman dengan ad-Dihlawi. Al-Sindi adalah seorang ulama yang memahami secara mendalam fiqh Iman Abu Hanifah dan Imam Ahmad, juga seorang pengikut tarekat Naqsabandi (Voll, 2015:38). Al-Sindi memiliki karya yang berjudul Syarh al-Hikam alAtho'iyah. Kemudian Muhammad bin Ali bin Muhammad bin Abdullah Asy-Syaukani Ash-Shan'ani, dikenal dengan nama asy-Syaukani. Dia memiliki karya antara lain 
tafsir Fathul Qadir al-Jami' baina Fann ar-Riwayat wad Dirayat fit TafsirAd-Durarul Bahiyyah fil Masa'ilil Fi'iqhiyah, Al-Qaulul Mufid fi Adillatil Ijtihad wat Taqlid.

Penelitian ini mengungkap pemikiran moderat Syah Waliyullah ad-Dihlawi yang hidup pada abad ke 17 Masehi, dalam sebuah karyanya yang berjudul Al-Inshaf fi Bayani Asbab al-Ikhtilaf. Sedangkan rumusan masalahnya, bagaimana pemikiran moderat adDihlawi dalam kitab Al-Inshaf fi Bayani Asbab al-Ikhtilaf?

Moderatisme atau paham moderat atau sikap moderat menjadi isu peradaban modern yang sedang menghadapi isu radikalisme. Secara akademis karya tulis ilmiah ini bertujuan menelaah pemikiran moderat ad-Dihlawi dalam kitab Al-Inshaffi Bayani Asbab al-Ikhtilaf. Adapun hasil penelitian ini dapat dijadikan sebagai materi pengayaan dalam pelatihan moderasi beragama dan perkuliahan di perguruan tinggi. Sedangkan secara aplikatif bertujuan agar dapat semakin menguatkan narasi moderasi beragama di Indonesia sebagaimana diserukan oleh Kementerian Agama.

Beberapa karya tulis ilmiah tentang ad-Dihlawi dalam 5 tahun terakhir yang dapat penulis temukan antara lain; Ikhtilaf Sahabat Menurut Syah Waliyullah Al-Dahlawi dan Pengaruhnya Terhadap Perkembangan Ijtihad dalam Aspek Hukum Keluarga, yang ditulis oleh Ihsan (2020). Dalam penelitiannya Ihsan menyimpulkan bahwa ikhtilaf sahabat sebagaimana dijelaskan oleh Syah Waliyullah al-Dahlawi berpengaruh terhadap ahwal alsyakhsiyyah, seperti pernikahan dan warisan. Arifin dan Hasbi (2020) menulis tentang Klasifikasi Sunnah Tasyri 'iyah dan Ghairu Tasyri'iyah Perspektif Pemikiran Ahmad Syah Waliyullah Al-Dahlawi. Keduanya menyimpulkan bahwa menurut al-Dahlawi, hadis tasyri'iyyah adalah hadis yang muncul dari posisi Nabi Saw sebagai seorang Rasul. Sedangkan hadis kategori ghairu tasyri'iyyah adalah hadis yang berasal dari sifat kemanusiaan Muhammad dan tidak wajib untuk ditiru, tapi hanya ideal untuk ditiru.

Selanjutnya Latifah (2019) menulis tentang Pemikiran Syah Waliyullah AlDahlawi Dalam Bidang Hadis (Studi Hadis Tabligh Al-Risalah dan Hadis Tabligh Ghayr Al-Risalah). Rafi (2020) menulis tentang Konsep Nasikh Wa Mansukh Menurut Syah Wali Allah Al-Dahlawi dan Implementasinya. Junoh dan Yusuf (2019) menulis tentang Pembangunan Kerohanian dan Intelektual Insan Berasaskan Empat Akhlak Utama Shah Wali Allah al-Dihlawi.

Tema-tema karya tulis ilmiah di atas memang meneliti pemikiran ad-Dihlawi, akan tetapi belum ada yang meneliti tentang moderatisme yang diindikasikan dalam kitab alInshaf fi Bayani Asbab al-Ikhtilaf. Oleh karena itu, karya tulis ini merupakan gagasan orisinil dan baru yang menyingkap sikap moderatisme ad-Dihlawi. 


\section{B. METODE PENELITIAN}

Jenis penilitian ini merupakan penelitian kepustakaan, karena obyek yang diteliti berupa teks dokumen. Teks dokumen tersebut kemudian dianalisis untuk mendapatkan suatu data. Dengan menggunakan metode deskriptif dan pendekatan kualitatif, diungkap informasi mengenai pemikiran moderat ad-Dihlawi. dalam kitab al-Inshaffi Bayani Asbab al-Ikhtilaf. Untuk melakukan pengungkapan informasi digunakan teknik content analysis (analisis isi). Untuk melihat konsistensi pemikiran moderat ad-Dihlawi, beberapa karyanya juga dimasukkan sebagai sumber sekunder penelitian.

\section{PEMBAHASAN}

\section{Biografi Singkat Syah Waliyullah ad-Dihlawi}

Syah Waliyullah ad-Dihlawi bernama lengkap Ahmad bin 'Abdurrahim Quṭbuddin ad-Dihlawi lahir di Delhi, India pada tanggal 4 Syawal 1114 H/21 Pebruari 1703 M dan wafat tanggal 19 Muharram 1176 H/10 Agustus 1762 M. Dia lebih dikenal dengan nama Waliyullah (peneliti ada yang menyebutnya dengan nama ad-Dihlawi). Ayahnya bernama 'Abdurrahîm (1644 - 1718 M) adalah seorang sufi, teolog dan ulama yang masyhur di India (Rizvi, 1980:20). Dia mendapatkan pendidikan sejak usia 5 tahun di madrasah ar-Rahimiyah yang didirikan dan dipimpin oleh ayahnya. Hafal alQur'an pada usia 7 tahun serta memperoleh pengetahuan tentang tafsir, hadis, tasawuf, fiqh, ilmu kalam dan juga politik di Madrasah yang sama hingga usia 16 tahun.

Berkat kecerdasan yang dimilikinya, dia menguasai ilmu-ilmu tersebut di atas secara memadai, sehingga sepeninggal ayahnya, dia diangkat sebagai tenaga pengajar di madrasahnya hingga usia 29 tahun. Selepas itu, ia melanjutkan perjalanan ilmiahnya ke Makah dan Madinah selama 14 bulan. Di Mekah dia berguru kepada seorang mufti yang bernama Tajudin al-Qal'i. Sedangkan di Madinah, dia berguru kepada seorang ulama hadits, bernama Abu Thahir ibn Ibrahim al-Madani, dan mendapatkan ijazah hadits darinya (Rizvi, 1980:215, Ahmad, 1984:252).

Ad-Dihlawi merupakan ulama yang produktif. Ahmad Ratib Armusy dalam pengantar Kitab al-Inshaffi Bayani Asbab al-Ikhtilaf menyebutkan bahwa ad-Dihlawi telah menulis lebih dari seratus karya dalam bahasa arab maupun persia, dalam berbagai bidang ilmu. Di antara karyanya yaitu:

- Al-Qoul al-Jamil fi Sawa as-Sabil

- Fuyudh al-Haramain 
- Hujjatullah al-Balighah

- Fath ar-Rahman

- Althafal-Quds

- Al-Musawwa

- Al-Intibah fi Salasil Auliya Allah wa Asanid Warisi Rasul Allah

- Al-Fauz al-Kabir fi Usul al-Tafsir

- Muqaddimah Dar Fann-i Tarjama-i Qur'an

- $\quad$ Ta'wil Ahadits

- Radd-î rawafidh

- Al-Nabidzat al-Abriziyyah fi al-Latifah al-'Aziziyyah

- Al-Khair al-Kațîr

- Al-Musaffa

- Al-Inshaffi Bayan Asbab al-Ikhtilaf

- Al-Durr al-Tamin fi Mubasyarat al-Nabi al-Aman

Karya ad-Dihlawi yang monumental yaitu Hujjatullah al-Balighah, sebuah kitab yang membahas aspek hadits, fiqih, kalam, alasan tentang hukum syari'ah dan rahasia-rahasianya. Adapun kitab Al-Inshaf fi Bayan Asbab al-Ikhtilaf merupakan karyanya yang terkenal juga, membahas tentang sebab-sebab perbedaan yang terjadi di kalangan ulama fiqih dan kesalahpahaman yang muncul di kalangan sahabat Nabi. Judul kitab Al-Inshaf fi Bayan Asbab al-Ikhtilaf dapat diartikan "upaya adil dan proporsional yang menerangkan sebab-sebab perbedaan". Secara sepintas, dengan melihat judulnya saja, kita dapat menemukan indikator sikap moderat yang dimiliki ad-Dihlawi.

Setelah melakukan perjalanan ilmunya, pada tahun 1145 H/1732 M ad-Dihlawi kembali ke Delhi, sementara kondisi sosial sedang mengalami pergolakan antara kaum muslimin dan penganut Hindu (Karim, 2003:105-6). Di internal umat Islam sendiri terjadi krisis keagamaan, seperti perseteruan antara Sunni dan Syi'ah dan pertentangan antar madzhab. Melalui pemikirannya, dia turut berupaya untuk menyatukan umat Islam di India (Subkhan, 2012:48-9).

\section{Kitab al-Inshaf fi Bayani Asbab al-Ikhtilaf}

\section{a. Versi Cetakan}

Berdasarkan penelusuran, penulis menemukan 2 cetakan dengan versi yang berbeda. Berdasarkan penelusuran, penulis menemukan 2 cetakan dengan versi yang 
berbeda. Versi yang pertama dalam format pdf yang diunggah di website https://ar.wikisource.org/ Tampaknya, versi pertama ini masih dalam bentuk manuskrip.
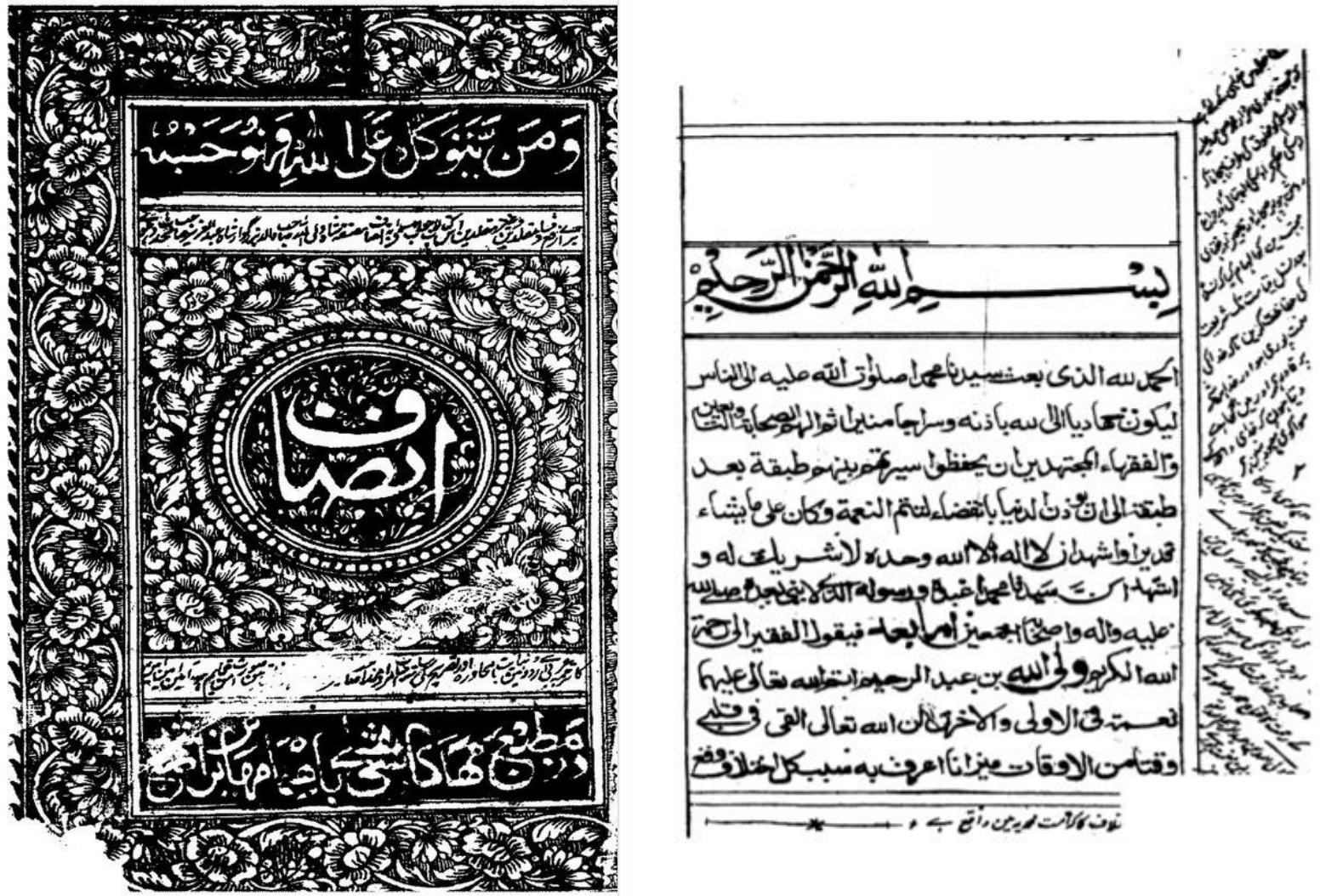

Gambar 1 Versi 1

Penjelasan:

\begin{tabular}{|l|l|}
\hline Penerbit dan Percetakan & Tidak diketahui \\
\hline Jumlah Halaman & 68 \\
\hline Tahun cetak & Tidak diketahui \\
\hline Tahun diunggah di website & September 2009 \\
\hline Gambar & $\begin{array}{l}\text { Gambar diperkecil dari ukuran } \\
\text { sebernarnya; cover dan halaman 1 }\end{array}$ \\
\hline
\end{tabular}

Cetakan versi ini dilengkapi dengan syarah (penjelasan) yang diletakkan di bagian tepi halaman. Dan dalam hal ini, penulis tidak akan terlalu jauh untuk meneliti bahasa yang digunakan dalam syarah tersebut. Jenis font terlihat tidak konsisten, hal ini menunjukan kitab ditulis dengan tangan. 


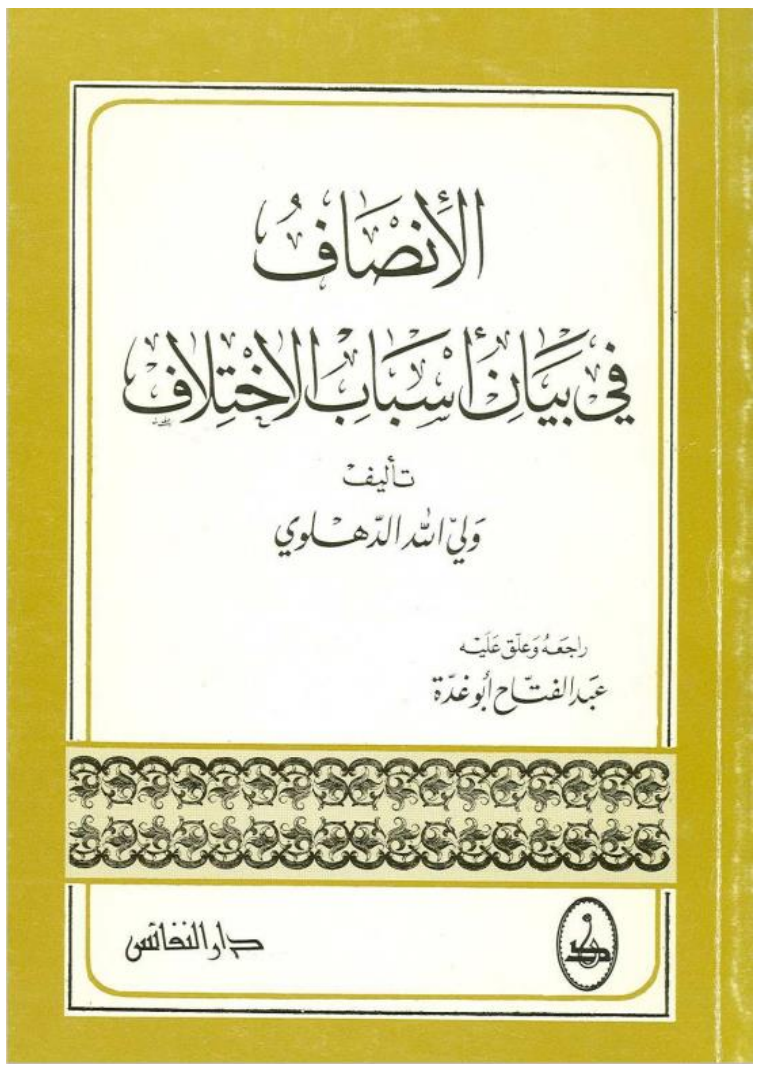

\section{متَعَمت}

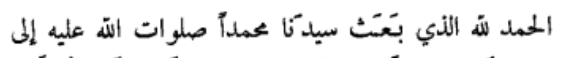

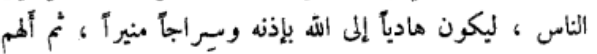

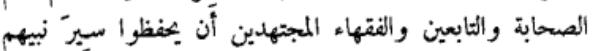

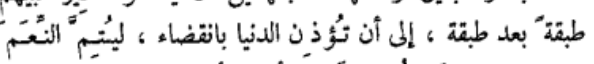

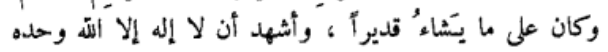

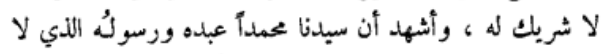

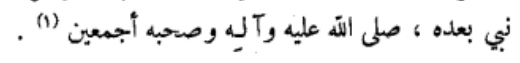

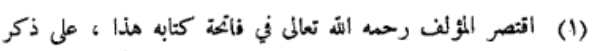

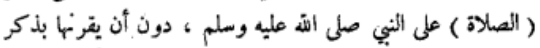

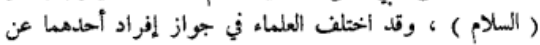

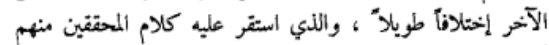

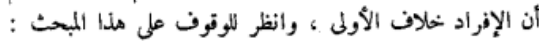

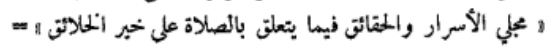

ir

Gambar 2 Versi 2

Penjelasan:

\begin{tabular}{|l|l|}
\hline Penerbit dan Percetakan & Dar an-Nafais \\
\hline Kota & Beirut Libanon \\
\hline Tahun cetak & Cetakan ke-3 tahun 1983 \\
\hline Dicek oleh & Abdul Fattah Abu Ghoddah \\
\hline Jumlah halaman & 113 \\
\hline Gambar & $\begin{array}{l}\text { Gambar diperkecil dari ukuran } \\
\text { sebernarnya; cover dan halaman 13 }\end{array}$ \\
\hline
\end{tabular}

Berbeda dengan cetakan versi sebelumnya, versi ini dilengkapi; pentahqiq (validator), informasi penerbit, tahun terbit, daftar isi, pengantar penerbit, pengantar tentang penulis dan ditulis menggunakan komputer (jenis font konsisten). Penulis menggunakan versi kedua sebagai obyek utama penelitian dengan pertimbangan; 1) sistematika jelas dan 2) mudah dibaca. 


\section{b. Isi Kitab}

Penulis menggunaan cetakan versi kedua sebagai obyek utama penelitian.

Adapun isi kitab dapat dijelaskan sebagai berikut:

1. Bab penjelaskan tentang sebab-sebab perbedaan yang terjadi di kalangan para sahabat dan tabi'in terkait masalah furu'iyah (cabang).

2. Bab penjelaskan tentang sebab-sebab perbedaan yang terjadi di kalangan madzhab-madzhab fikih.

3. Bab penjelaskan tentang sebab-sebab perbedaan yang terjadi di kalangan ahli hadits dan ahli ro' $y u$.

4. Bab penjelasan tentang keadaan masyarakat sebelum abad ke-4 Hijriah

5. Bab penjelasan tentang keadaan masyarakat setelah abad ke-4 Hijriah

6. Uraian tentang taqlid dalam 4 madzhab.

\section{Moderatisme ad-Dihlawi dalam Kitab Al Inshaf fi Bayani Asbab al Ikhtilaf}

Membicarakan tentang perkembangan Islam setelah wafatnya Rasulullah Saw., tidak bisa berlepas diri dari kenyataan adanya perbedaan di antara umat Islam sendiri, terutama terkait dengan pemahaman syari'ah (hukum Islam). Menurut an-Nabhani, adanya perbedaan masalah furu' di kalangan ulama, disebabkan perbedaan thoriqot alistinbath yang berarti metode penggalian hukum (an-Nabhani, 1994:386). Perbedaan ini kemudian dipegang secara berlebihan oleh orang-orang yang mengaku pengikut madzhab. Hal ini mulai terjadi setelah abad ke-4 hijriah (ad-Dihlawi, 1983:93). Di antara mereka ada yang mengaku sebagai pihak yang paling benar seraya menyalahkan pihak lain. Mereka mengikutinya tanpa ilmu pengetahuan, dan berpuas diri menjadi generasi taqlid. Dari keadaan ini, tumbuh ekosistem pertentangan antar pengikut madzhab yang di kemudian hari membawa umat Islam ke dalam krisis keagamaan.

Ad-Dihlawi mengalami krisis keagamaan yang cukup pelik, tidak hanya konflik antar aliran dalam Islam -Sunni dan Syi'ah-, namun juga konflik antar pengikut madzhab. Antar umat Islam dirundung konflik internal. Energi mereka habis untuk mempertahankan dan mendaku sebagai madzahab/ aliran yang paling benar, Akibatnya umat Islam mudah dipecah belah dan tertinggal dari peradaban. Melihat kondisi ini, adDihlawi menulis sebuah karya yang menjelaskan sebab-sebab perbedaan. Seakan-akan dia menyeru kepada umat Islam: "jangan larut dalam perbedaan, karena sesungguhnya perbedaan itu merupakan keniscayaan”. 
Terjadinya perbedaan menurut ad-Dihlawi dibagi menjadi 4 fase.

a. Perbedaan pendapat yang terjadi di kalangan para sahabat dan tabi'in terkait masalah furu'iyah (cabang)

Rasulullah Saw. merupakan pemimpin negara sekaligus sumber hukum. Pada masa itu, ketika ada suatu permasalah yang terjadi dan membutuhkan keputusan hukum, maka dihadapkan kepada Rasulullah Saw, dan beliau memutuskannya berdasarkan wahyu.

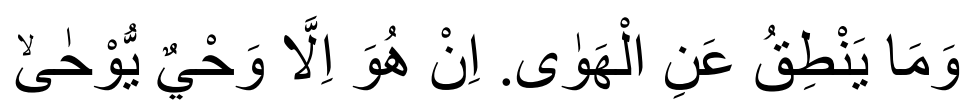

"dan tidaklah yang diucapkannya itu (Al-Qur'an) menurut keinginannya. Tidak lain (Al-Qur'an itu) adalah wahyu yang diwahyukan (kepadanya)"

Rasulullah dimintai fatwa oleh para sahabat mengenai beberapa persoalan maka dia memberinya fatwa. Beliau dilapori tentang beberapa kasus maka beliaumenuntaskannya. Semua fatwa, putusan, dan penolakan kepada pelaku kemungkaran tersebut disaksikan oleh khalayak ramai.

Setelah Rasulullah Saw. wafat, tidak ada lagi pemberi fatwa dan putusan bagi umat Islam, yang kududukannya sama seperti beliau. Maka, ketika Abu Bakar maupun Umar, sebagai pemimpin umat Islam, ketika dimintai fatwa putusan suatu masalah yang belum di dengar oleh keduanya dari Rasulullah, mereka akan bertanya, " aku belum pernah mendengar ucapan Rasulullah tentang masalah itu" (ad-Dihlawi, 1983:17). Hal ini wajar, karena sahabat -layaknya manusia pada umumnya- juga memiliki urusan yang menjadi tanggung jawabnya. Mereka juga mengurus rumah tangga, kewajiban mencari nafkah, dan lain-lain. Kondisi ini menjadikan mereka tidak bisa setiap saat mendengarkan hadits dan fatwa Rasulullah Saw. Sebagian ada yang mendengar langsung dari Rasulullah Saw atau melihat langsung tindakannya. Adapula yang mendengar dari sahabat lain yang langsung mendengar atau melihat Rasulullah Saw. Sedangkan sahabat yang tempat tinggalnya jauh dari Madinah, yang tidak berkesempatan menghadiri majlis Rasulullah Saw., hanya bisa mendengar dari sahabat lain (Subkhan, 2018:90-1).

Seiring dengan perkembangan dan perluasan kekuasaan Islam, para sahabat menyebar ke berbagai negeri. Di sana, kedudukan mereka menjadi tumpuan untuk menyelesaikan berbagai persoalan hukum yang terjadi di tengah umat. Mereka dihadapkan pada permasalahan baru akibat perkembangan kondisi sosial kultural. Untuk menyelesaikan permasalahan baru tersebut, ada kalanya mereka 
menemukannya dalam riwayat yang bersumber dari Rasulullah Saw. Namun, ada kalanya mereka tidak dapat menemukan sumber istibath-nya (pengambilan hukum). Untuk masalah yang tidak dapat ditemukan sumber istinbath-nya mereka akan berijtihad dengan pendapatnya sendiri berdasarkan pemahaman 'illat hukum (ad-Dihlawi, 1983:22-3). Dengan adanya ijtihad individu yang dilakukan oleh para sahabat ini, dari sinilah muncul perbedaan-perbedaan. Sebab, dalam melakukan berijitihad, masing-masing memiliki pemahaman yang berbeda-beda. Di samping itu juga, pengaruh kondisi sosial kultural yang juga berbeda-beda. Perbedaan pemahaman dan kondisi sosial kultural yang berbeda-beda ini, dapat menyebabkan perbedaan hasil ijtihad.

Ad-Dihlawi (1983) secara rinci menjelaskan sebab-sebab terjadinya perbedaan di kalangan sahabat dan tabi' in sebagai berikut.

1) Seorang sahabat pernah mendengar suatu putusan atau fatwa hukum (dari Rasulullah, sementara yang lain tidak mengetahuinya sehingga dia berijtihad dengan pendapatnya.

2) Para sahabat melihat Rasulullah melakukan suatu perbuatan, lalu sebagian menganggapnya sebagai suatu bentuk qurbah (pendekatan diri kepada Allah) dan sebagian lagi menganggapnya sebagai ibahah (kebolehan).

3) Perbedaan persepsi para sahabat

4) Perbedaan yang disebabkan karena faktor lupa

5) Perbedaan penalaran

6) Perbedaan dalam memahami 'illat hukum

7) Perbedaan dalam mengompromikan dua pendapat yang berbeda

Dengan adanya tujuh faktor penyebab perbedaan tersebut, tentu menghasilkan putusan atau fatwa hukum yang berbeda di antara para sahabat.

b. Perbedaan pendapat yang terjadi di kalangan madzhab-madzhab fikih.

Masa terbaik dalam Islam setelah Rasulullah Saw. adalah masa sahabat, karena mereka mengalami interaksi langsung dengan Rasulullah Saw. Dengan menjalani kehidupan sehari-hari bersama Rasulullah Saw., mereka memiliki pemahaman yang memadai tentang apa yang dikehendaki oleh Rasulullah Saw. dalam setiap ucapan, perbuatan maupun ketetapannya. Kenyataan ini disepakati oleh para ulama, dan bahkan dibenarkan oleh Rasulullah Saw. melalui haditsnya. 


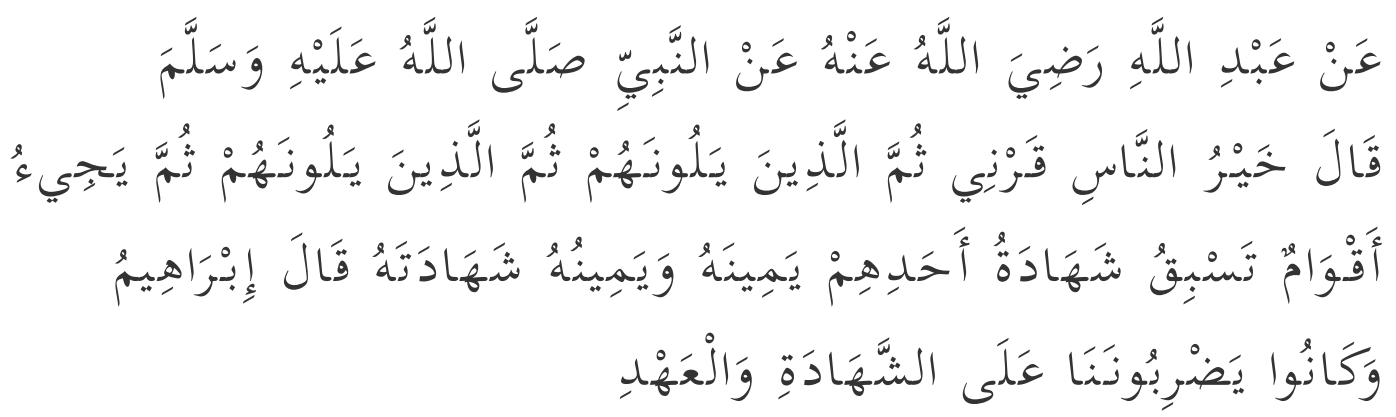

"dari 'Abdullah ra. dari Nabi Saw. bersabda: "Sebaik-baik manusia adalah orang-orang yang hidup pada zamanku (generasiku) kemudian orang-orang setelah mereka kemudian orang-orang setelah mereka. Kemudian akan datang sebuah kaum yang persaksian seorang dari mereka mendahului sumpahnya dan sumpahnya mendahului persaksiannya". Ibrahim berkata; "Dahulu, mereka (para shahabat) mengajarkan kami tentang bersaksi dan memegang janji (Mereka memukul kami bila melanggar perjanjian dan persaksian) "

Berbekal pemahaman yang memadai tersebut di atas, maka mereka melakukan ijtihad untuk memutuskan fatwa permasalahan baru. Hasil ijtihad yang dilakukan oleh para sahabat menjadi sebuah fatwa yang patut untuk diikuti. Namun, meskipun masing-masing sahabat memiliki hasil ijtihad yang berbeda-beda, hal ini tidak kemudian memunculkan aliran madzhab dalam Islam (belum muncul terminologi Madzhab). Yang penting diketahui, pada era sahabat ini pedoman ijtihad belum dibangun secara konstruktif dan sistematis, sebagaimana era imam madzhab.

Masa sahabat berlalu dan ilmu-ilmu agama telah menyebar ke berbagai penjuru negeri. Kondisi sosial kultural semakin berkembang lagi. Pun demikan, permasalahan yang muncul di tengah umat semakin komplek. Sementara, fatwafatwa hasil ijtihad para sahabat ada kalanya masih relevan dengan perkembangan zaman, ada kalanya memerlukan penelaahan ulang.

Memasuki era madzhab, pola istibath al-ahkam (penggalian hukum) hampir sama dengan era sahabat dan tabi'in (ad-Dihlawi, 1983:34). Mereka telah mendapatkan pelajaran dari tabi' in tentang ibadah, mu'amalah, munakahat, jinayah dan berbagai persoalan yang ada di tengah masyakarat. Mereka juga meriwayatkan hadits dari para tabi'in, dan mengetahui putusan hukum dari para mufti di beberapa daerah. Berbekal pengetahuannya tersebut, mereka dijadikan sebagai tokoh, panutan dan rujukan oleh masyarakat untuk dimintai fatwa.

Menurut ad-Dihlawi (1983:35-8), secara umum metode istinbath al-ahkam yang digunakan oleh tabi'in dan diikuti oleh para pakar fikih sebagai berikut. 
1) Mereka berpegangan pada sunnah Rasulullah, baik yang musnad maupun yang mursal, dan beristidlal (mengambil dalil) dari beberapa ucapan sahabat dan tabi'in

2) Jika beberapa hadits Rasulullah berbeda-beda dalam menanggapi suatu persoalan, maka para tabi'in berpedoman pada ucapan sahabat.

3) Jika sahabat dan tabi'in berbeda pendapat dalam suatu persoalan maka yang baik untuk diikuti menurut ulama adalah madzhab penduduk setempat atau guru-guru setempat.

4) Jika penduduk suatu negara sepakat atas suatu masalah maka mereka akan memeganginya dengan teguh.

5) Jika para tabi'in tidak mendapatkan jawaban masalah dari sumber-sumber yang mereka kuasai, maka mereka berusaha mentakhrîj ucapan sahabat dan meneliti beberapa indikasi dan tuntunan syara'nya.

Berdasarkan metode di atas, kemudian imam Madzhab merumuskan sumber-sumber istinbath al-ahkam.

1) Imam Abu Hanifah

Imam Abu Hanifah lahir tahun 699 Masehi di Kufah, Irak. Dalam melakukan istinbath al-ahkam, mendasarkan pada tujuh hal pokok, yaitu: AlQur'an, Sunah, fatwa sahabat (aqwal al-shahabah), qiyas (analogi), istihsan ijma' dan 'urf (as-Syak'ah, 1991:170). Imam Abu Hanifah juga menggunakan maslahah mursalah yaitu menarik manfaat atau menolak mudharat (hal-hal yang merugikan) dalam rangka memelihara tujuan syara'/hukum Islam (alGhozali, 1997:250). Abu Hanifah banyak mempergunakan metode qiyas untuk menyelesaikan masalah yang tidak ditemukan hukumnya dalam dua sumber utama hukum Islam (Minhajuddin, 2004:38).

2) Imam Malik

Imam Malik lahir pada tahun 717 Masehi di Madinah, 13 tahun setelah kelahiran Imam Abu Hanifah. Sumber-sumber fiqh iman Maliki terdiri atas al-Qur'an, Sunah, qoul ash-Shohabat, ijma', perkara yang diperbuat oleh penduduk Madinah, istihsan, 'urf, saddu ad-dzaroi' dan maslahah mursalah (asy-Syak'ah, 1991:108-10). Secara khusus, Imam Maliki menetapkan syaratsyarat maslahah mursalah. 
3) Imam Syafi'i

Imam Syafi'i merupakan salah satu murid Imam Maliki. Lahir tahun 767 Masehi di Ghaza Palestina. Dia dinobatkan sebagai peletak dasar ilmu ushul fiqh dituangkan dalam karya yang berjudul ar-Risalah. Dalam melakukan istinbath al-ahkam, imam Syafi'i mendasarkan pada Al-Qur'an, sunah, ijma' dan qiyas (asy-Syak'ah, 1991:121-2).

4) Imam Ahmad bin Hanbal

Imam Ahmad ibn Hanbal lahir di Baghdad pada bulan Rabi' al-Awwal tahun $164 \mathrm{H}$ bertepatan dengan tahun 780 M. Pada saat itu, Baghdad di bawah pemerintahan bani 'Abbasiyyah yang sedang dipimpin oleh al-Mahdi. Adapun metode istinbath al ahkam Imam Ahmad yaitu al-Qur'an, sunah, fatwa sahabat, qiyas, istishhab, maslahat, saddu adz-dzaroi' (asy-Syak'ah, 1991:220 \& 225). Imam Ahmad tidak menerima qiyas sebagai sumber fikihnya karena beliau menganggap bahwa qiyas itu batal dalam ajaran agama Islam.

Penjelasan di atas menunjukan bahwa semua imam madzhab menjadikan al-Qur'an dan sunah sebagai sumber utama istinbath ahkam, namun ada perbedaan pada selain keduanya. Di dalam kitab al-Inshaf fi Bayani Asbab al-Ikhtilaf tidak ditemukan penjelasan secara rinci mengenai sumber-sumber istinbath al-ahkam imam Madzhab sebagaimana di jelaskan di atas. Namun, ad-Dihlawi menjelaskan karakteristik masing-masing imam Madzhab.

Imam Malik, menurut ad-Dihlawi (1983:38), merupakan orang yang paling menguasai dan terpercaya dalam hal hadits yang diriwayatkan oleh penduduk Madinah dari Rasulullah Saw. Dengan penguasaan yang mendalam terhadap hadits, beliau menyusun kitab al-Muwaththa', sebuah kitab hadits yang berisi fatwa hukum Islam. Baginya, peran sunah (hadits) sangat penting sebagai sumber hukum Islam. Hal ini yang kemudian membuat Imam Malik dikenal sebagai ahl al-Hadits. Imam Malik hidup pada masa pemerintahan al-Mansur, khalifah kedua bani Abbasiyah yang berkuasa dari tahun 754 sampai 775 Masehi. Khalifah pernah meminta Imam Malik untuk menjadikan kitab al-Muwaththa' sebagai panduan resmi negara, namun Imam Malik menolaknya (Hosen, 2018:19).

Karakteristik Imam Abu Hanifah dijelaskan oleh ad-Dihlawi (1983:39) sebagai ulama yang madzhabnya dekat dengan madzhab Ibrahim al-Nakha'iy. Al- 
Nakha'iy dikenal sebagai tokoh ahl al-Ra'yi, yaitu kelompok ulama yang menetapkan hukum dengan menggunakan analisa pemikiran atas suatu permasalahan yang tidak ditemukan ketentuannya secara tegas dan pasti dalam nash al-Quran dan sunnah mutawâtirah atau sunnah masyhûrah (Madzkur, tt:114). Oleh karena, ulama memasukkan Imam Abu Hanifah ke dalam kelompok ahl ar-Ro'yi.

Selanjutnya yaitu Imam Syafi'i. Ad-Dihlawi (1983:41) menjelaskan, bahwa Imam Syafi'i melakukan penelaahan karya ulama pendahulunya dan menemukan beberapa hal yang menghalanginya untuk mengikuti corak pemikiran mereka. Hasil penelaahannya kemudian membuat Imam Syafi'i mengambil sikap berbeda dengan pendahulunya. Misalnya, Imam Syafi'i sangat menentang penggunaan istihsan sebagai salah satu metode istibath al-ahkam. Juga tidak menggunakan hadits mursal sebagai dalil kecuali memenuhi syarat.

Adapun mengenai Imam Ahman bin Hanbal, tidak ditemukan penjelasan memadai dalam buku karya ad-Dihlawi ini. Hanya beberapa indikator yang menunjukan bahwa Imam Ahmad sangat berpegang teguh kepada al-Qur'an dan Sunah. Dalam hal Hadits, Imam Ahmad bin Hanbal merupakan ulama ahli dalam hal hadits-hadits yang syadz dan langka serta mampu mengkompromikan dalil-dalil yang bertentangan (ad-Dihlawi, 1983:103)

c. Perbedaan pendapat yang terjadi di kalangan ahli hadits dan ahli ro'yu

Kondisi perbedaan yang terjadi antara ahli hadits dan ahli ra'yu digambarkan oleh ad-Dahlawi (1983:64) dengan mengutip penjelasan Abu Sulaiman al-Khaththabi dalam kitab Ma'alim as-Sunan. Menurut Al-Khathathabi (1932:3) bahwa ilmu (istibath al-ahkam) terbagi menjadi 2 yaitu kelompok pendukung hadits dan atsar (ahl al-hadits) vis a vis kelompok pendukung fikih dan penalaran (ahl al-ro'yi). Sebenarnya, keduanya dibutuhkan dan saling melengkapi untuk memahami maksud dan tujuan syara'. Ahl hadits diibaratkan sebagai pondasi pokok, sedangkan ahl al-ro'yi diibaratkan sebagai bangunan. Sebuah bangunan yang tidak dibangun di atas pondasi yang kokoh, maka akan mudah roboh. Sedangkan pondasi yang kokoh tanpa ada bangunan di atasnya, maka hanya sekedar pondasi kosong dan akhirnya akan rusak. Kenyataannya, kedua elemen tersebut saling berjauhan dan tidak memperlihatkan komitmen bersama untuk menegakkan kebenaran ajara agama Islam. 
Adapun penyebab kondisi yang saling berhadapan tersebut, adalah fokus kajian masing-masing kelompok. Kelompok ahl al-hadits kebanyakan berfokus pada periwayatan, pengumpulan sanad, pemisahan hadits gharib dan syadz di antara hadits yang kebanyakan maudlu' atau maqlub. Sedangkan ahl al-ro'yi berfokus pada hasil penalaran mereka untuk menghasilkan suatu fatwa hukum dan kurang memperhatikan kategori hadits yang digunakan sebagai dalil istinbath al-ahkam AlKhathathabi (1932:3-4).

d. Perbedaan pendapat setelah abad keempat Hijriyah

Setelah abad ke empat Hijriyah perbedaan perdapat bukan lagi merupakan hal wajar dalam kemanusiaan. Maksudnya, perbedaan metode dalam memahami nash-nash syara', niscaya akan menghasilkan produk hukum yang berbeda pula, dan hal ini tidak kemudian melahirkan pemutlakan pendapat benar atau salah. Lalu apa yang terjadi setelah abad ke empat Hijriyah? ad-Dihlawi (1983:87) menukil pendapat Imam al-Ghozali yang menjelaskan bahwa akibat kekhalifahan dipimpin oleh orang-orang yang tidak memiliki kecakapan dalam bidang syari'ah, maka mereka meminta bantuan ahli fikih untuk berfatwa. Di antara ahli fikih ada yang masih memegang teguh prinsip, ada juga yang ingin dekat dengan kekuasaan. Jabatan ahli fikih saat itu merupakan jabatan terhormat. Akhirnya, banyak orang belajar agama hanya untuk mendapatkan kedudukan ahli fikih di lingkungan kekuasaan. Hasilnya, fatwa-fatwa hukum yang dihasilkan sudah tidak murni lagi.

Masih menurut al-Ghozali, sebagaimana dikutip oleh ad-Dihlawi (1983:88), bahwa pada era ini terjadi perdebatan yang semakin tajam terutama dalam hal fikih. Perdebatan tidak lagi dilihat sebagai khasanah ilmu dan pengembangan wawasan, tapi memperdebatkan pendapat madzhab siapakah yang lebih utama. Kondisi ini berlanjut dari generasi ke generasi, bahkan hingga sekarang.

Ad-Dihlawi (1983:93) menilai generasi pasca abad ke empat hijriyah sebagai generasi yang berpuas diri dengan taqlid. Taqlid yaitu menerima pendapat orang lain tanpa mengetahui dalilnya, baik dalam bentuk melakukan perbuatan atau meninggalkan suatu perbuatan (Hosen, 2004:11). Terkait taqlid dibagi menjadi dua, wajib dan haram (ad-Dihlawi, tt:27). Ada tiga penyebab generasi taqlid, yaitu: 1) persaingan dan pertentangan di antara ulama fikih, 2) ketidakcakapan hukum dan penyelewengan pemimpin, dan 3) kebodohan pemimpin dan masyarakat yang 
terkadang meminta fatwa kepada orang yang tidak mengetahui ilmu hadits secara memadai (ad-Dihlawi, 1983:94)

Penyebab terjadinya perbedaan pendapat telah dijelaskan oleh ad-Dihlawi secara obyektif, sebagaimana tersebut di atas. Hal ini bertujuan untuk memberikan pemahaman kepada umat Islam bahwa perbedaan dalam memahami syari'at Islam merupakan hal yang lumrah dan wajar. Perbedaan pendapat telah terjadi di antara sahabat, tabi' in dan imam madzhab. Mereka berbeda karena memiliki metode istinbath al-ahkam yang berbeda pula. Berbeda metode, maka menghasilkan produk hukum yang berbeda. Namun, meskipun mereka berbeda, tidak ada pihak yang mengaku pendapat dirinya yang paling benar dan yang lain salah. Obyektifitas ad-Dihlawi dalam menyajikan sebab-sebab perbedaan, merupakan salah satu indikator sikap moderat beliau.

Ad-Dihlawi menyeru sikap moderat dalam menyikapi perbedaan pendapat. Beliau mencontohkan sikap tabi'in seperti Sa'ad bin Musayyab dan Ibrahim an-Nakha'i yang eklektik, dengan cara mengumpulkan produk-produk hukum fikih dari ulama sebelumnya (sahabat), kemudian menelaahnya dan menggunakannya. Sa'ad bin Musayyab pakar fikih yang tinggal di Madinah, sedangkan Ibrahim an-Nakha'i pakar fikir yang tinggal di Kufah. Sampai di sini, tidak ada pertentangan antara keduanya, meskipun memiliki corak fikih yang berbeda (ad-Dihlawi, 1983:31-2). Di kalangan Imam Madzhab, ad-Dihlawi mencontohkan sikap Imam Syafi'i terhadap Imam Ahmad. Meskipun Imam Syafi'i dan Imam Ahmad memiliki metode istinbath yang berbeda tetapi di antara mereka terjalin relasi yang baik dan indah. Imam Syafi'i mengakui keunggulan Imam Ahmad dalam menguasai hadist-hadits shahih (ad-Dihlawi, 1983:4).

"Asy-Syafi'i berkata kepada Imam Ahmad, "Engkau lebih mengetahui daripada saya tentang hadits-hadits yang shahih. Jika ada suatu hadits yang shahih, beritahulah aku, agar bisa kucari. Baik itu di Kufah, Bashrah, maupun Syam." (Riwayat Ibnu Rumam)". (ad-Dihlawi, 1983:4).

Perbedaan yang terjadi antara ahl al-hadits dengan ahl al-ro'yi, seharusnya disikapi dengan bijak, yaitu kompromi dan saling melengkapi. Sikap ad-Dihlawi sejalan dengan Imam Hasan al-Bashri ketika menyikapi pertentangan antara ahl alhadits dengan ahl al-ro'yi. Imam Hasan al-Bashri mengatakan bahwa hendaknya ulama ahli hadits mengkompromikan hadits dengan pendapat para imam mujtahid dari kalangan tabi'in dan generasi sesudahnya. Sedangkan ahli takhrij (ahl al-ro'yi) 
memperhatikan hadits, sehingga tidak menyalahi keterangan yang shahih. Maka ketika melakukan istinbath al-ahkam, tidak semata-mata berpegang pada pendapatnya/perenungannya (ro' $y u$ ), namun diperkuat oleh hadits maupun atsar (adDihlawi, 1983:62).

Moderatisme ad-Dihlawi semakin terlihat ketika menyajikan riwayat imam Madzhab dalam menyikapi perbedaan. Misalnya perbedaan membaca basmalah atau tidak, mengeraskan atau melirihkan. Hal ini pernah terjadi pada zaman Imam Abu Hanifah, Imam Syafi'i dan ashhab mereka. Mereka bersedia makmum di belakang Imam Madinah yang bermadzhab Maliki walaupun imam tidak membaca basmalah, baik keras maupun pelan. Imam Ahmad bin Hanbal bersedia menjadi makmum di belakang Imam Malik maupun Saad bin Musayyab, meskipun mereka berbeda pendapat tentang mengeluarkan darah (mimisan) dan berbekam. Sebagaimana diketahui Imam Malik berpendapat bahwa mengeluarkan darah (mimisan) dan berbekam tidak membatalkan wudlu. Sedangkan menurut Imam Ahmad bin Hanbal, hal tersebut membatalkan wudlu. Imam Syafi'i pernah shalat Subuh tanpa Qunut di dekat makam (kuburan) Imam Abu Hanifah. Keduanya berbeda pendapat soal qunut subuh (ad-Dihlawi, 1983:108-10).

Memang, ada generasi yang memiliki tradisi ilmiah berupa aktifitas merangkum dan meringkas pendapat ulama kemudian membahas perbedaan di antara mereka. Kemudian mereka memilih dan memegang teguh pendapat imam tertentu. Misalnya Ibnu Rusyd dalam karyanya yang berjudul Bidayat al-Mujathid wa Nihayat alMuqtashid. Namun, keteguhan mereka terhadap suatu madzhab, semata-mata disebabkan karena faktor naluri yang manusiawi-karena setiap manusia pasti mencintai pendapat golongan atau kaumnya. Yang perlu diketahui bahwa tradisi semacam ini bukanlah bentuk fanatisme keagamaan (ad-Dihlawi, 1983:108). Meskipun mereka memilih madzhab tertentu, tidak ada pernyataan "madzhab pilihanku yang paling benar, dan yang lain salah”. Ini yang diajarkan oleh imam Madzhab dalam maqolah yang sangat masyhur.

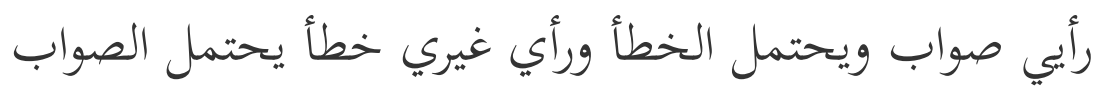

"Pendapatku benar, tapi bisa jadi salah. Dan pendapat selain ku itu salah, tapi bisa jadi benar". 


\section{KESIMPULAN}

Perbedaan pendapat dalam memahami syara' sudah terjadi sejak masa sahabat. Kalau merunut sejarah, bisa ditemukan misalnya riwayat hadits tentang larangan sholat asar kecuali di Bani Quraidzah. Dalam memahami larangan Rasulullah Saw ini, para sahabat memiliki pemahaman yang berbeda-beda. Padahal, di antara mereka ada Rasulullah Saw, sebagai pemimpin dan sekaligus hakim. Jika demikian, maka tidak heran, ketika memasuki masa sahabat dan tabi'in, perbedaan terus terjadi dengan ruang lingkup yang lebih luas seiring dinamika umat Islam. Ketika memasuki era Imam Madzhab, cakupan perbedaan pendapat semakin luas dan intensif. Perbedaan ini semakin kuat, karena masing-masing memiliki metode istinbath al-ahkam.

Ad-Dihlawi menyajikan data secara obyektif penyebab perbedaan pendapat yang terjadi di kalangan sahabat, tabi'in, Imam Madzhab, ahl al-hadits dan ahl ar-ro'yi serta perbedaan pendapat yang terjadi setelah abad ke empat hijriyah. Perbedaan pendapat berubah menjadi pemicu konflik antar umat Islam, ketika dibawa ke ranah kekuasaan. Hal ini terjadi setelah abad ke empat Hijriyah. Orang berlomba-lomba untuk menjadi ahli fikih dengan harapan mendapatkan posisi terhormat di sisi penguasa. Akhirnya, umat Islam hanya mempelajari persoalan khilafiyah antar madzhab, yang semakin memperluas konflik perbedaan pendapat. Pada posisi ini, muncul klaim-klaim kebenaran sepihak. Padahal sahabat, tabi'in dan imam madzhab tidak mengajarkan hal ini.

Moderatisme Ad-Dihlawi tercermin dalam sikapnya yang mengajak kepada umat Islam yang terlibat dalam konflik perbedaan pendapat, agar meneladani sikap-sikap moderat yang ditunjukan oleh para sahabat, tabi'in dan Imam Madzhab. Di antara sahabat ada perbedaan pendapat, di antara tabi' in ada perbedaan pendapat, misalnya antara tabi'in yang tinggal di Madinah dengan tabi' in yang tinggal di kufah. Di antara imam Madzhab juga ada perbedaan. Namun, adanya perbedaan tersebut tidak menjadikan sebagai pemicu konflik di antara mereka. Sebaliknya, justru mengakui keunggulan sesamanya. Dengan demikian, maka adanya perbedaan pendapat menunjukan betapa luasnya khazanah ilmuilmu keislaman. Sehingga umat Islam semakin mudah dalam mengamalkan ajaran agamanya. 


\section{DAFTAR PUSTAKA}

Ad-Dihlawî, Syāh Walî Allāh. (1983). al-Inșāf fî Bayāni Asbabi al-Ikhtilāf, Beirut: Dar anNafais.

(2005). Hujjatullah al-Bālighah, Beirut: Dar al-Jail. cet. I.

(tt). 'Iqd al-Jid fi Ahkam al-Ijtihad wa al-Taklid, tt:tt.

Ahmad, Jamil. (1984). Hundred Great Muslims, Pakistan: Ferozsons.

Al-Ghazali, Abu Hamid Muhammad. (1997). Al-Mustashfa Min 'Ilm al-Ushul, Beirut: Muassasah al-Risalah. Juz I.

Al-Khaththabi, Abu Sulaiman. (1932). Ma'alim as-Sunan. tt: Mathba'ah al-'Ilmiah Halab.

Al-Nabhani, Taqiyuddin (1994), Asy-Syakhsiyah al-Islamiyah, Juz I, Beirut: Darul Ummah.

Arifin, Johar dan M. Ridwan Hasbi. (2020). Klasifikasi Sunnah Tasyri'iyah dan Ghairu Tasyri'iyah Perspektif Pemikiran Ahmad Syah Waliyullah Al-Dahlawi.. An-Nida' 44.1. DOI: http://dx.doi.org/10.24014/an-nida.v44i1.12500

Asy-Syak'ah, Mustofa Muhammad (1991). Al-Aimmah al-Arba'ah. Mesir: Dar al Kutub alMishri.

Hanafi, A. (1970). Pengantar dan Hukum Syarah Hukum Islam.Cet. I, Jakarta: Bulan Bintang

Hosen, Ibrahim. (2004). Taklid dan Ijtihad. t.th: Artikel Yayasan Paramadina.

Ihsan, M. (2020). Ikhtilaf Sahabat Menurut Syah Waliyullah al-Dahlawi dan Pengaruhnya Terhadap Perkembangan Ijtihad dalam Aspek Hukum Keluarga. Hukum Islam 20.2, 276. DOI: http://dx.doi.org/10.24014/jhi.v20i2.9760

Karim, Abdul. (2003). Sejarah Islam di India, Yogyakarta: Bunga Grafies Production

Latifah, Ishmah Nanda Ayu (2019). Pemikiran Syah Waliyullah Al-Dahlawi Dalam Bidang Hadis (Studi Hadis Tabligh Al-Risalah dan Hadis Tabligh Ghayr Al-Risalah). Diss. IAIN KUDUS

Madzkur, Muhammad Salam. (tt). Manahij al-jtihad fí al-Islam, Kuwait: Al-'Ashriyyah

Minhajuddin. (2004). Pengembangan Metode Ijtihad Dalam Perspektif Fikih Islam. Jurnal Zaitun Vol. I No. II April

Rafi, M. (2020), Konsep Nasikh Wa Mansukh Menurut Syah Wali Allah Al-Dahlawi dan Implementasinya”. Jurnal Ilmiah Mahasiswa Raushan Fikr, 9(2), 112-129. DOI: https://doi.org/10.24090/jimrf.v9i2.4142

Rizvi, Saiyid Athar Abbas. (1980). Syāh Walî- Allāh and His Times A Study of Eigteenth Century Islam, Politics and Society in India Australia: Ma'arifat Publishing House.

Subkhan, A. (2012). Ijtihad dan relevansinya dalam pembaruan pemikiran hukum Islam (studi atas pemikiran Syāh Wali Allāh Ad-Dihlawî 1114 H/1703 M-1176 H/1762 M) (Tesis, IAIN Walisongo).

----------.(2018). Nilai-Nilai Karakter Kesungguhan Ulama Dalam Mencari Hadits. Andragogi: Jurnal Diklat Teknis Pendidikan dan Keagamaan, 6(1), 84-102. 
Voll, John (1975). Muḥammad Hayyat al-Sindi and Muḥammad ibn 'Abd al-Wahhab: An Analysis of an Intellectual Group in Eighteenth-Century Madina. Bulletin of the School of Oriental and African Studies, University of London. 